\title{
PENERAPAN PIDANA PASAL 92 AYAT (1) HURUF A JO PASAL 17 AYAT (2) HURUF B UNDANG-UNDANG NOMOR 18 TAHUN 2013 TENTANG PENCEGAHAN DAN PENGRUSAKANHUTAN (ANALISIS PUTUSAN PENGANDILAN NEGERI SAROLANGUN NOMOR: 16/PID.SUS/2015/PN.SRL)
}

\author{
Sahuri Lasmadi \\ Dosen Fakultas Hukum Universitas Jambi \\ Email : slasmadi@gmail.com \\ Elly Sudarti \\ Dosen Fakultas Hukum Universitas Jambi \\ Email : elly.sudarti@yahoo.com
}

\begin{abstract}
ABSTRAK
Penelitian ini bertujuan: (1) Untuk menganalisis putusan hakim dalam menentukan unsur Pasal 92 ayat (1) Huruf a Jo Pasal 17 ayat (2) huruf b Undang-Undang Nomor 18 Tahun 2013 untuk dapat diterapkan kepada pelaku Pengrusakan Hutan (Analisis Putusan pengadilan Negeri sarolangun Nomor: 16/PID.SUS/2015/PN.SRL); (2) Untuk menganalisis pertanggungjawaban pidana pelaku tindak pidana pengrusakan hutan sebagaimana diatur pada Pasal 92 ayat (1) Huruf a Jo Pasal 17 ayat (2) huruf b UndangUndang Nomor 18 Tahun 2013. Hasil penelitian: (1) Majelis Hakim untuk membuktikan unsur objektif dan unsur subjektif dari Pasal 92 ayat (1) Huruf a Jo Pasal 17 ayat (2) huruf b Undang-Undang Nomor 18 Tahun 2013 berdasarkan fakta di persidangan dan fakta yuridis serta hal-hal yang memberatkan dan meringankan secara sosiologis dari terdakwa. Unsur objektif dan unsur subjektif diuraikan oleh Hakim secara detail dan atas pertimbangan tersebut Majelis Hakim yakin bahwa subyek hukum (terdakwa) bersalah, sehingga dijatuhkan pidana; (2) Penentuan pertanggungjawaban pidana terhadap pelaku tindak pidana pengrusakan hutan pada Pasal 92 ayat (1) Huruf a Jo Pasal 17 ayat (2) huruf b Undang-Undang Nomor 18 Tahun 2013 pada Putusan Pengadilan Negeri Sarolangun Nomor: 16/PID.SUS/2015/PN.SRL yaitu dengan memperhatikan Actus Reus dan guilty mind atau mens rea, yaitu adanya hubungan batin dengan perbuatan dan menurut ukuran yang biasa dipakai masyarakat sebagai ukuran untuk menetapkan ada tidaknya hubungan batin antara pelaku dengan perbuatannya yang diatur dalam ketentuan pidana Pasal 92 ayat (1) Huruf a Jo Pasal 17 ayat (2) huruf b Undang-Undang Nomor 18 Tahun 2013.
\end{abstract}

Kata Kunci: penerapan pidana, pelaku, pencegahan dan pengrusakan hutan

\section{ABSTRACT}

This study aims: (1) To analyze the judge's decision in determining the element of Article 92 paragraph (1) Letter a Jo Article 17 paragraph (2) letter b Law Number 18 of 2013 to be applied to perpetrators of Forest Destruction (Analysis of District Court Decisions sarolangun Number: 16 / PID.SUS / 2015 / PN.SRL); (2) To analyze the criminal liability of the perpetrator of a crime of forest destruction as stipulated in Article 92 paragraph (1) Letter a Article Article 17 paragraph (2) letter b of Act Number 18 of 2013. Research 
results: (1) Panel of Judges to prove objective elements and subjective elements of Article 92 paragraph (1) Letter a Jo Article 17 paragraph (2) letter b Law Number 18 Year 2013 based on the facts in the trial and juridical facts as well as things that incriminate and sociologically alleviate the defendant. Objective elements and subjective elements are elaborated by the Judge in detail and based on these considerations the Panel of Judges is convinced that the legal subjects (defendants) are guilty, so that they are convicted; (2) Determination of criminal responsibility for the perpetrators of crimes of forest destruction in Article 92 paragraph (1) Letter a Jo Article 17 paragraph (2) letter b of Act Number 18 of 2013 on the Decision of the Sarolangun District Court Number: 16 / PID. 2015 / PN.SRL that is by paying attention to Actus Reus and guilty mind or mens rea, namely the existence of an inner connection with actions and according to the measure commonly used by the community as a measure to determine whether there is an inner connection between the perpetrator and his actions stipulated in criminal provisions Article 92 paragraph (1) Letter a Jo Article 17 paragraph (2) letter b of Act Number 18 of 2013.

Keywords: criminal application, perpetrators, prevention and destruction of forests

\section{Pendahuluan}

Hutan Indonesia sebagai karunia dan anugerah Tuhan Yang Maha Esa yang diamanatkan kepada bangsa Indonesia merupakan unsur utama sistem penyangga kehidupan manusia dan merupakan modal dasar pembangunan nasional yang memiliki manfaat nyata, baik manfaat ekologi, sosial budaya, maupun ekonomi agar kehidupan dan penghidupan bangsa Indonesia berkembang secara seimbang dan dinamis (Penjelasan Umum UU Nomor 18 Tahun 2013).

Hutan Indonesia merupakan salah satu hutan tropis terluas di dunia sehingga keberadaanya menjadi tumpuan keberlangsungan kehidupan bangsa-bangsa di dunia, khususnya dalam mengurangi dampak perubahan iklim global. Pemanfaatan dan penggunaannya harus dilakukan secara terencana, rasional, optimal, dan bertanggung jawab sesuai dengan kemampuan daya dukung serta memperhatikan kelestarian fungsi dan keseimbangan lingkungan hidup guna mendukung pengelolaan hutan dan pembangunan kehutanan yang berkelanjutan bagi kemakmuran rakyat.

Hal itu sesuai dengan ketentuan Pasal 33 ayat (3) Undang-Undang Dasar Negara Republik Indonesia Tahun 1945 yang menyatakan bahwa bumi, air, dan kekayaan alam yang terkandung di dalamnya dikuasai oleh negara dan dipergunakan untuk sebesar-besarnya kemakmuran rakyat. Dengan demikian, hutan sebagai salah satu sumber kekayaan alam bangsa Indonesia dikuasai oleh Negara (Penjelasan Umum UU Nomor 18 Tahun 2013).

Penguasaan sumber daya hutan oleh negara memberi wewenang kepada pemerintah untuk (i) mengatur dan mengurus segala sesuatu yang berkaitan dengan hutan, kawasan hutan, dan hasil hutan; (ii) menetapkan kawasan hutan dan/atau mengubah status kawasan hutan; (iii) mengatur dan menetapkan hubungan hukum antara orang dan hutan atau kawasan hutan dan hasil hutan; serta (iv) mengatur perbuatan hukum mengenai kehutanan. Selanjutnya, pemerintah sesuai dengan kewenangannya dapat memberikan izin 
kepada pihak lain yang memenuhi persyaratan untuk melakukan kegiatan di bidang kehutanan.

Akhir-akhir ini perusakan hutan semakin meluas dan kompleks. Perusakan itu terjadi tidak hanya di hutan produksi, tetapi juga telah merambah ke hutan lindung ataupun hutan konservasi. Perusakan hutan telah berkembang menjadi suatu tindak pidana kejahatan yang berdampak luar biasa dan terorganisasi serta melibatkan banyak pihak, baik nasional maupun internasional. Kerusakan yang ditimbulkan telah mencapai tingkat yang sangat mengkhawatirkan bagi kelangsungan hidup bangsa dan negara. Oleh karena itu, penanganan perusakan hutan harus dilakukan secara luar biasa.

Upaya menangani perusakan hutan sesungguhnya telah lama dilakukan, tetapi belum berjalan secara efektif dan belum menunjukkan hasil yang optimal. Hal itu antara lain disebabkan oleh peraturan perundangundangan yang ada belum secara tegas mengatur tindak pidana perusakan hutan yang dilakukan secara terorganisasi. Oleh karena itu, diperlukan payung hukum dalam bentuk undang-undang agar perusakan hutan terorganisasi dapat ditangani secara efektif dan efisien serta pemberian efek jera kepada pelakunya.

Cakupan perusakan hutan yang diatur dalam UU Nomor 18 Tahun 2013 Tentang Pencegahan dan Perusakan Hutan meliputi proses, cara, atau perbuatan merusak hutan melalui kegiatan pembalakan liar dan/atau penggunaan kawasan hutan secara tidak sah. Adapun pembalakan liar didefinisikan sebagai semua kegiatan pemanfaatan hasil hutan kayu secara tidak sah yang terorganisasi, sedangkan penggunaan kawasan hutan secara tidak sah meliputi kegiatan terorganisasi yang dilakukan di dalam kawasan hutan untuk perkebunan dan/atau pertambangan tanpa izin Menteri.

Upaya pencegahan perusakan hutan dilakukan melalui pembuatan kebijakan oleh Pemerintah dan pemerintah daerah serta dengan peningkatan peran serta masyarakat. Dalam rangka pemberantasan perusakan hutan, Undang-Undang ini mengatur kategori dari perbuatan perusakan hutan terorganisasi, baik perbuatan langsung, tidak langsung, maupun perbuatan terkait lainnya. Guna meningkatkan efektivitas pemberantasan perusakan hutan, Undang-Undang ini dilengkapi dengan hukum acara yang meliputi penyidikan, penuntutan, dan pemeriksaan di sidang pengadilan.

Undang-Undang Nomor 18 Tahun 2013 Tentang Pencegahan dan Perusakan Hutan Pasal 17 ayat (2) huruf b mengatur tentang "melakukan kegiatan perkebunan tanpa Izin Menteri di dalam kawasan hutan", lebih lanjut Pasal 92 ayat (1) huruf a "melakukan kegiatan perkebunan tanpa Izin Menteri di dalam kawasan hutan sebagaimana dimaksud dalam Pasal 17 ayat (2) huruf b.

Pada Putusan Pengadilan Nomor: 16/Pid.Sus/2015/PN.Srl pelanggaran terhadap Pasal 92 Ayat (1) huruf a Jo Pasal 17 ayat (2) huruf b Undangundang RI Nomor 18 Tahun 2013 Tentang Pencegahan dan Pemberantasan Perusakan Hutan. Pengadilan menyatakan terdakwa (1) telah terbukti secara sah dan meyakinkan bersalah melakukan tindak pidana "dengan sengaja melakukan kegiatan perkebunan tanpa Izin Menteri 
di dalam kawan hutan"; (2) Menjatuhkan pidana terhadap Terdakwa tersebut dengan pidana penjara selama 3 (tiga) tahun penjara dan pidana denda sebesar Rp 1.500.000.000,- (satu milyar lima ratus juta rupiah), dengan ketentuan apabila denda tersebut tidak dibayar oleh Terdakwa maka diganti dengan pidana kurungan selama 1 (satu)bulan; Menarik untuk diteliti adalah persoalan penerapan pidananya, karena yang selama ini penegak hukum dalam penerapkan pasal hanya melihat pada perbuatan nyata (Actus Reus) tanpa mempertimbangkan Niat jahat pelaku (Mens Rea), sehingga pidana dijatuhkan tidak menyentuh kepada pelaku yang sesungguhnya. Oleh sebab itu tim peneliti tertarik untuk meneliti, Penerapan Pidana Pasal 92 Ayat (1) Huruf A Jo Pasal 17 Ayat (2) Huruf B Undang-Undang Nomor 18 Tahun 2013 Tentang Pencegahan Dan Pengrusakan Hutan (Analisis Putusan pengadilan negeri Sarolangun Nomor: 16/PID.SUS/2015/PN.SRL.

\section{Rumusan Masalah}

Berdasarkan uraian yang telah dikemukakan perumusan masalah yang akan diteliti, sebagai berikut:

1. Bagaimana hakim dalam menentukan unsur-unsur Pasal 92 ayat (1) Huruf a Jo Pasal 17 ayat (2) huruf b Undang-Undang Nomor 18 Tahun 2013 untuk dapat diterapkan kepada pelaku Pengrusakan Hutan (Analisis Putusan Pengadilan Negeri sarolangun Nomor: 16/PID.SUS/2015/PN.SRL.

2. Bagaimana menentukan pertanggungjawaban pidana terhadap pelaku tindak pidana pengrusakan hutan sebagaimana diatur pada Pasal 92 ayat (1) Huruf a Jo Pasal 17 ayat (2) huruf b Undang-Undang Nomor 18 Tahun 2013 Tentang Tentang Pencegahan Dan Pengrusakan Hutan (Analisis Putusan Pengadilan Negeri sarolangun Nomor: 16/PID.SUS/2015/PN.SRL.

\section{Metode Penelitian}

Tipe penelitian ini adalah yuridis normatif, yaitu suatu proses untuk menemukan aturan hukum, prinsip hukum maupun doktrin hukum guna menjawab isu hukum yang dihadapi. Pendekatan penelitian, yaitu: pendekatan perundang-undangan, yaitu "metode penelitian dengan berusaha memahami asas-asas dari suatu peraturan perundang-undangan". Untuk penafsiran terhadap peraturan perundang-undangan, penelitian ini juga menggunakan metode pendekatan konseptual. Adalah metode pendekatan yang mempelajari pandanganpandangan dan doktrin-doktrin dalam ilmu hukum sehingga peneliti akan menemukan ide yang melahirkan pengertian, konsep, dan asas hukum yang relevan dengan isu yang dihadapi. pendekatan kasus dengan cara menganalisis kasus-kasus yang ada dengan indikasi kasus pengrusakan hutan. Analisis Bahan Hukum dilakukan dengan cara melakukan interpretasi, menilai dan mengevaluasi perundangundangan yang berhubungan dengan masalah yang diteliti.

\section{Pembahasan \\ Penentuan Unsur-Unsur Pasal 92 Ayat (1) huruf a Jo Pasal 17 ayat (2) huruf b Undang-Undang RI Nomor 18 Tahun 2013 Tentang Pencegahan dan Pemberantasan Pengrusakan Hutan}




\section{Terhadap Pelaku Pada Putusan pengadilan Nomor: \\ 16/Pid.Sus/2015/PN.Srl}

Tindak pidana sering di istilahkan sebagai "Perbuatan Pidana", perbuatan pidana dimaksud adalah perbuatan yang oleh aturan hukum pidana dilarang dan diancam dengan pidana barang siapa yang melanggar larangan tersebut. Dalam Undang-Undang Republik Indonesia Nomor 18 Tahun 2013 Tentang Pencegahan Pemberantasan Perusakan Hutan, perbuatan yang dilarang dirumuskan dalam beberapa pasal, antara lain sebagai berikut ini:

Pasal 17:

(2) Setiap orang dilarang:

a. membawa alat-alat berat dan/atau alat-alat lainnya yang lazim atau patut diduga akan digunakan untuk melakukan kegiatan perkebunan dan/atau mengangkut hasil kebun di dalam kawasan hutan tanpa izin Menteri;

b. melakukan kegiatan perkebunan tanpa izin Menteri di dalam kawasan hutan;

c. mengangkut dan/atau menerima titipan hasil perkebunan yang berasal dari kegiatan perkebunan di dalam kawasan hutan tanpa izin;

d. menjual, menguasai, memiliki, dan/atau menyimpan hasil perkebunan yang berasal dari kegiatan perkebunan di dalam kawasan hutan tanpa izin; dan/atau

e. membeli, memasarkan, dan/atau mengolah hasil kebun dari perkebunan yang berasal dari kegiatan perkebunan di dalam kawasan hutan tanpa izin.

Dengan demikian seluruh hal-hal yang dilarang dalam Undang-Undang Republik Indonesia Nomor 18 Tahun 2013 Tentang Pencegahan Pemberantasan Perusakan Hutan adalah tindak pidana kehutanan, bagi subjek hukum yang melanggarnya, maka akan diproses untuk dipertanggungjawabkan secara pidana. Dalam menjabarkan sesuatu rumusan delik ke dalam unsur-unsurnya, maka yang pertama dapat dijumpai adalah disebutkan sesuatu tindakan manusia, dengan tindakan itu seseorang telah melakukan sesuatu tindakan yang terlarang oleh undang-undang. Setiap tindak pidana yang terdapat di dalam Kitab Undang-undang Hukum Pidana (KUHP) pada umumnya dapat dijabarkan ke dalam unsurunsur yang terdiri dari unsur subjektif dan unsur objektif.

Unsur subjektif adalah unsur-unsur yang melekat pada diri si pelaku atau yang berhubungan dengan diri si pelaku, dan termasuk ke dalamnya yaitu segala sesuatu yang terkandung di dalam hatinya. Sedangkan unsur objektif adalah unsur-unsur yang ada hubungannya dengan keadaan-keadaan, yaitu di dalam keadaan-keadaan mana tindakan-tindakan dari si pelaku itu harus 
dilakukan.

(P.A.F.

Lamintang, 1992: 173)

Dalam kaitannya dengan pendapat Lamintang di atas, Pasal 17 ayat (2) huruf b UndangUndang Nomor 18 Tahun 2013, dirumuskan Setiap orang dilarang, "melakukan kegiatan perkebunan tanpa izin Menteri di dalam kawasan hutan"; Pasal 17 Ayat (2) huruf $b$ tersebut, maka dapat diuraikan unsur-unsur objektif dan unsur-unsur subjektif sebagai berikut:

\section{Unsur objektif adalah:}

a. Perbuatan: melakukan kegiatan perkebunan tanpa izin Menteri di dalam

kawasan hutan;

Dalam Pasal 1 angka 2 dinyatakan bahwa kawasan hutan adalah wilayah tertentu yang ditetapkan oleh Pemerintah untuk dipertahankan

keberadaannya sebagai hutan tetap, (artinya bukan hutan pribadi). Pada Pasal 1 angka 5 dinyatakan bahwa penggunaan kawasan hutan secara tidak sah adalah kegiatan terorganisasi yang dilakukan di dalam kawasan hutan untuk perkebunan dan/atau pertambangan tanpa izin menteri.

Dalam kaitannya dengan Putusan Nomor: Nomor:

16/Pid.Sus/2015/PN.Srl;

Unsur setiap orang dapat diuraikan sebagai berikut:

Menimbang, bahwa yang dimaksud dengan kata Orang Perorang sama dengan kata setiap orang. Hal ini secara eksplisit ditegaskan dalam Pasal 1 Ayat 21 Undang-Undang RI Nomor 18 Tahun 2013 Tentang Pencegahan dan Pemberantasan Perusakan Hutan yang berbunyi sebagai berikut; "Setiap orang adalah perseorangan dan/atau" korporasi yang melakukan perbuatan perusakan hutan";

Menimbang, bahwa menilik maksud dari rumusan pembuat Undang-undang terhadap sub unsur ini, secara interpretasi gramatikal maka dapat diformulasi- kan sebagai berikut;

1. Setiap orang adalah siapa saja orangnya yang dalam hal ini dia ditujukan kepada tiap subyek hukum dalam arti manusia, sebagai pendukung hak dan kewajiban yang dapat mempertanggungjawabka n perbuatannya sedangkan Perseorangan adalah yang berkaitan dengan orang secara pribadi;

2. Korporasi adalah kumpulan orang dan/atau kekayaan yang terorganisasi, baik berupa badan hukum maupun bukan badan hukum;

Oleh Karena dalam rumusan pasal ini mengandung syarat alternatif dimana aturan hukum yang memberikan beberapa syarat (kondisi) yang jika salah satu syarat tersebut terpenuhi maka akibat hukum akan diterapkan. Karena syaratnya alternative maka cukup tepenuhi salah satu saja 
dari syarat tersebut dan akibat hukumnya sudah bisa diterapkan;

Menimbang, bahwa terdakwa dipersidangan pada pokoknya telah menerangkan bahwa, keseluruhan identitas yang tercantum dalam dakwaan Penuntut Umum adalah benar diri terdakwa sendiri, demikian pula keseluruhan saksi-saksi dipersidangan pada pokoknya telah menerangkan bahwa yang dimaksud dengan Sudirman Hutagaol anak dari Manintang Hutagaol adalah diri terdakwa, yang saat ini dihadapkan dan diadili di persidangan Pengadilan Negeri Sarolangun;

$$
\text { Menimbang, bahwa }
$$

terdakwa dipersidangan juga telah ditanyakan oleh Majelis Hakim, apakah terdakwa ada hubungannya dengan badan usaha atau badan hukum, baik secara perkerjaan ataupun menerima upah dari pekerjaan tersebut, dan terdakwa mengatakan tidak ada;

Menimbang, bahwa oleh karenanya berdasarkan uraian di atas terebut maka jelaslah unsur setiap orang dapat dikenakan dalam sub unsur ini, karenanya unsur pertama pasal ini telah terpenuhi menurut hukum;

2. Unsur subjektif: dengan sengaja

Untuk
objektif tersebut, penuntut
umum harus dapat meyakinkan
hakim dalam persidangan
pengadilan, dengan menampilkan
saksi-saksi untuk memberikan
keterangan yang berhubungan

satu sama lainnya dan barang bukti misalnya alat untuk membakar hutan, keadaankeadaan yang menunjukkan adanya pembakaran misalnya: asap. Peta Kawasan Hutan dan melampirkan Peraturan Pemerintah, bahwa kawasan tersebut dilindungi, dll. Selanjutnya bukti perizinan, Sedangkan unsur subjektifnya: dengan sengaja dapat dilihat dari kondisi Pelaku, bahwa pelaku mempunyai niat dengan perlengkapan yang sedemikian dan mengetahui bahwa kawasan hutan dimana TKP hutan yang dibakarnya tersebut merupakan kawasan Hutan yang diberikan Hak Pengusahaan Hutan Tanaman Industri (HPHTI kepada PT SAMHUTANI.

Dengan sengaja melakukan kegiatan Perkebunan Tanpa Izin Menteri di dalam Kawasan Hutan dalam kaitannya dengan Putusan Nomor: 16/Pid.Sus/2015/PN.Srl;

Menimbang, bahwa untuk membuktikan sub unsur ini Pengadilan akan me-ngemukakan pengertian dan fakta-fakta hukum sebagai berikut; Menimbang, dalam unsur ini mengandung beberapa pengertian seperti terurai di bawah ini;

1. Dengan sengaja. Berbicara dengan sengaja atau kesengajaan, dalam hukum pidana kesengajaan dapat di bagi dalam beberapa macam yaitu sebagai berikut;

a. Sengaja atau opzet adalah "willen dan wetens artinya; "Pembuat harus menghendaki 
(willen) melakukan perbuatan tersebut: dan juga harus mengerti (wetens) akan akibat daripada perbuatan itu" sedangkan dilihat dari bentuknya dikenal tiga bentuk kesengajaan atau opzet yaitu:

1) Kesengajaan sebagai maksud yaitu "Si pembuat (dader) mengehendaki akibat dari perbuatannya". Artinya pembuat sudah mengetahui sebelumnya bahwa akibat dari perbuatannya tidak akan terjadi maka sudah barang tentu tidak akan melakukan perbuatan tersebut;

2) Kesengajaan sebagai kepastian atau keharusan. Dalam teori ini mengatakan bahwa: "Perbuatan yang dilakukan tidak bertujuan untuk mencapai akibat yang menjadi dasar dari delik, tetapi ia tahu benar bahwa akibat itu pasti akan mengikuti perbuatan itu";

3) Kesengajaan sebagai kesadaran akan kemungkinan pada dasarnya bentuk kesengajaan ini timbul: "Apabila seseorang melakukan sesuatu perbuatan dan menimbulkan sesuatu akibat tertentu";

Bahwa dengan kata lain adalah suatu kesengajaan tentunya berhubungan dengan sikap bathin seseorang yang didakwa melakukan tindak pidana, dan Majelis Hakim menyadari tidaklah mudah untuk menentukan sikap batin sesorang untuk menilai unsur diketahui atau patut diketahui itu, benar-benar ada pada diri si pelaku, lebih-lebih bagaimanakah keadaan batinnya pada waktu orang tersebut melakukan perbuatannya, oleh karena itulah sikap batinnya harus disimpulkan dari keadaan lahir yang tampak dari luar;

2. Melakukan kegiatan Perkebunan tanpa izin Menteri di dalam kawasan hutan. Bahwa terhadap pengertian sub unsur pasal ini pengadilan sependapat dengan Penuntut Umum;

Perbuatan pada Pasal 17 Ayat (2) Huruf B berkaitan dengan Pasal 92 Ayat (1) Huruf A, sebagai berikut: "melakukan kegiatan perkebuanan tanpa izin menteri di dalam kawasan hutan sebagaimana dimaksud dalam Pasal 17 Ayat (2) huruf b, dan / atau;

Dipidana dengan pidana penjara paling singkat 3 (tiga) tahun dan paling lama

10 (sepuluh) tahun serta pidana denda paling sedikit $\mathrm{Rp}$ 1.500.000.000 (satu milyar lima ratus juta rupiah) dan paling banyak Rp 5.000.000.000 (lima milyar rupiah). 
Cara Menentukan Kesalahan Dan Sanksi Pidana Terhadap Pelaku Sebagai Dasar Pertanggungjawaban Pidana Tindak Pidana Kehutanan Pasal 92 Ayat 1 Huruf A Jo Pasal 17 Ayat (2) Huruf b UU Nomor 18 Tahun 2013

\begin{abstract}
Berkaitan dalam asas
\end{abstract} hukum pidana yaitu Geen straf zonder schuld, actus non facit reum nisi mens sir rea, bahwa tidak dipidana jika tidak ada kesalahan, maka pengertian tindak pidana itu terpisah dengan yang dimaksud pertanggungjawaban tindak pidana. Tindak pidana hanyalah menunjuk kepada dilarang dan diancamnya perbuatan itu dengan suatu pidana, kemudian apakah orang yang melakukan perbuatan itu juga dijatuhi pidana sebagaimana telah diancamkan akan sangat tergantung pada soal apakah dalam melakukan perbuatannya itu si pelaku juga mempunyai kesalahan.

Dalam kebanyakan rumusan tindak pidana, unsur kesengajaan atau yang disebut dengan opzet merupakan salah satu unsur yang terpenting. Dalam kaitannya dengan unsur kesengajaan ini, maka apabila di dalam suatu rumusan tindak pidana terdapat perbuatan dengan sengaja atau biasa disebut dengan opzettelijk, maka unsur dengan sengaja ini menguasai atau meliputi semua unsur lain yang ditempatkan dibelakangnya dan harus dibuktikan. Sengaja berarti juga adanya kehendak yang disadari yang ditujukan untuk melakukan kejahatan tertentu. Maka berkaitan dengan pembuktian bahwa perbuatan yang dilakukannya itu dilakukan dengan sengaja, terkandung pengertian menghendaki dan mengetahui atau biasa disebut dengan willens en wetens. Yang dimaksudkan di sini adalah seseorang yang melakukan suatu perbuatan dengan sengaja itu haruslah memenuhi rumusan willens atau haruslah menghendaki apa yang ia perbuat dan memenuhi unsur wettens atau haruslah mengetahui akibat dari apa yang ia perbuat.

Dasar hukum adanya tindak pidana adalah asas legalitas, sedangkan dasar hukum dapat dipidananya pembuat tindak pidana adalah asas kesalahan. Ini berarti bahwa pembuat tindak pidana hanya akan dipidana jika ia mempunyai kesalahan dalam melakukan tindak pidana tersebut. Kapan seseorang dikatakan mempunyai kesalahan merupakan hal yang menyangkut masalah pertanggungjawaban pidana. Seseorang mempunyai kesalahan bilamana pada waktu melakukan tindak pidana, dilihat dari segi kemasyarakatan ia dapat dicela oleh karena perbuatannya.

Berkaitan dengan pertanggungjawaban pidana itu, ada dua aliran yang selama ini dianut, yaitu aliran indeterminisme dan aliran determinisme. Kedua aliran tersebut membicarakan 
hubungan antara kebebasan kehendak dengan ada atau tidak adanya kesalahan. Kedua aliran tersebut adalah:

1. Kaum indeterminis (penganut

indeterminisme), yang pada dasarnya berpendapat, bahwa manusia mempunyai kehendak bebas dan ini merupakan sebab dari segala keputusan kehendak. Tanpa ada kebebasan kehendak maka tidak ada kesalahan; apabila tidak ada kesalahan, maka tidak ada pencelaan, sehingga tidak ada pemidanaan.

2. Kaum determinis

(penganut

determinisme)

mengatakan, bahwa manusia tidak mempunyai kehendak bebas. Keputusan kehendak ditentukan sepenuhnya oleh watak (dalam arti nafsunafsu manusia dalam hubungan kekuatan satu sama lain) dan motif-motif, ialah perangsang-perangsang datang dari dalam atau dari luar yang mengakibatkan watak tersebut. ini berarti bahwa seseorang tidak dapat dicela atas perbuatannya atau dinyatakan mempunyai kesalahan, sebab ia tidak punya kehendak bebas. Namun meskipun diakui bahwa tidak punya kehendak bebas, itu tak berarti bahwa orang yang melakukan tindak pidana tidak dapat

dipertanggungjawabka

$\mathrm{n}$ atas perbuatannya (Soedarto, 1990: 87).

Justru karena tidak adanya kebebasan kehendak itu maka ada pertanggungjawaban dari seseorang atas perbuatannya. Tetapi reaksi terhadap perbuatan yang dilakukan itu berupa tindakan (maatregel) untuk ketertiban masyarakat, dan bukannya pidana dalam arti "penderitaan sebagai buah hasil dari kesalahan oleh sipembuat". Indonesia sebagai penganut sistem civil law, mengakui asas kesalahan sebagai satu-satunya asas dalam hal pertanggungjawaban pidana. Namun, dalam praktiknya juga mengakui adanya pengecualian terhadap asas tersebut. Hal itu terjadi karena perkembangan masyarakat yang sangat cepat menuntut diberlakukannya berbagai model atau sistem pertanggungjawaban pidana. Melihat kecenderungan yang demikian itu, pembentuk Konsep KUHP Baru menganggap penting untuk mencantumkan bentuk atau model sistem pertanggungjawaban yang merupakan pengecuclian dari asas kesalahan ke dalam KUHP Nasional. 


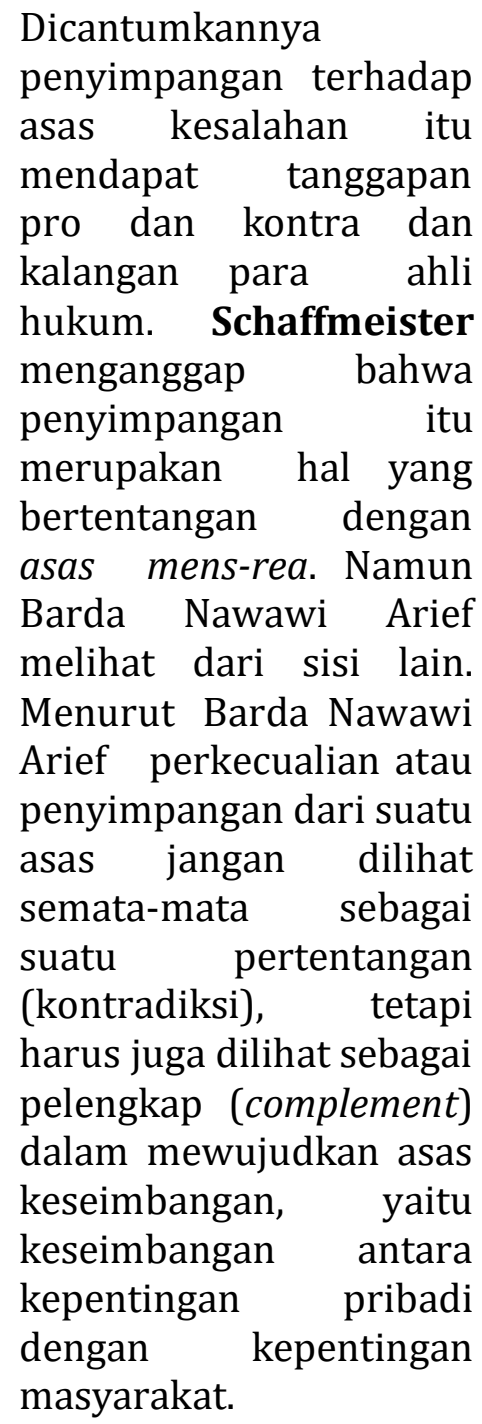

Keseimbangan antara kedua kepentingan itulah yang oleh Barda Nawawi Arief dinamakan Asas Monodualistik. (Barda Nawawi, 2008: 112-113).

Unsur kesalahan dalam hukum pidana sangatlah penting, suatu perbuatan tidak membuat orang bersalah kecuali jika terdapat batin yang salah. Jadi batin yang salah atau guilty mind atau mens rea ini adalah kesalahan yang merupakan sifat subyektif dari tindak pidana karena berada didalam diri pelaku oleh karena itu kesalahan memiliki dua segi, yaitu segi psikologi dan segi normatif. Segi psikologi kesalahan harus dicari didalam batin pelaku yaitu adanya hubungan batin dengan perbuatan yang dilakukan sehingga ia dapat mempertanggungjawabkan perbuatannya. Segi normatif yaitu menurut ukuran yang biasa dipakai masyarakat sebagai ukuran untuk menetapkan ada tidaknya hubungan batin antara pelaku dengan perbuatannya.

Berdasarkan hal tersebut maka pertanggungjawaban pidana atau kesalahan menurut hukum pidana, terdiri atas tiga syarat yaitu:

1. Kemampuan bertanggung jawab atau dapat dipertanggung jawabkan dari si pembuat.

2. Adanya perbuatan melawan hukum yaitu suatu sikap psikis si pelaku yang berhubungan dengan kelakuannya yaitu:
a. Disengaja
b. Sikap kurang hati-hati atau lalai

3. Tidak ada alasan pembenar atau alasan yang menghapuskan pertanggung jawaban pidana bagi si pembuat.

Kemampuan untuk membeda-bedakan antara perbuatan yang baik dan yang buruk, adalah merupakan faktor akal (intelektual factor) yaitu dapat membedakan perbuatan yang diperbolehkan dan yang 
tidak. Dan kemampuan untuk menentukan kehendaknya menurut keinsyafan tentang baik buruknya perbuatan tersebut adalah merupakan faktor perasaan (volitional factor) yaitu dapat menyesuaikan tingkah lakunya dengan keinsyafan atas mana yang diperbolehkan dan mana yang tidak. Sebagai konsekuensi dari dua hal tadi maka tentunya orang yang tidak mampu menentukan kehendaknya menurut keinsyafan tentang baik buruknya perbuatan, dia tidak mempunyai kesalahan kalau melakukan tindak pidana, orang demikian itu tidak dapat dipertanggung jawabkan.

Oleh karena kemampuan bertanggung jawab merupakan unsur kesalahan, maka untuk membuktikan adanya kesalahan unsur tadi harus dibuktikan lagi. Mengingat hal ini sukar untuk dibuktikan dan memerlukan waktu yang cukup lama, maka unsur kemampuan bertanggung jawab dianggap diam-diam selalu ada karena pada umumnya setiap orang normal bathinnya dan mampu bertanggung jawab, kecuali kalau ada tanda-tanda yang menunjukkan bahwa terdakwa mungkin jiwanya tidak normal. Dalam hal ini, hakim memerintahkan pemeriksaan yang khusus terhadap keadaan jiwa terdakwa sekalipun tidak diminta oleh pihak terdakwa. Jika hasilnya masih meragukan hakim, itu berarti bahwa kemampuan bertanggung jawab tidak berhenti, sehingga kesalahan tidak ada dan pidana tidak dapat dijatuhkan berdasarkan asas tidak dipidana jika tidak ada kesalahan.

Untuk menentukan adanya pertanggung jawaban, seseorang pembuat dalam melakukan suatu tindak pidana harus ada "sifat melawan hukum" dari tindak pidana itu, yang merupakan sifat terpenting dari tindak pidana. Tentang sifat melawan hukum apabila dihubungkan dengan keadaan psikis (jiwa) pembuat terhadap tindak pidana yang dilakukannya dapat berupa "kesengajaan" (opzet) atau karena "kelalaian" (culpa). Akan tetapi kebanyakan tindak pidana mempunyai unsur kesengajaan bukan unsur kelalaian. Hal ini layak karena biasanya, yang melakukan sesuatu dengan sengaja.

Dalam teori hukum pidana Indonesia kesengajaan itu ada tiga macam, yaitu:

1. Kesengajaan yang bersifat tujuan bahwa dengan kesengajaan yang bersifat tujuan, si pelaku dapat dipertanggung jawabkan dan mudah dapat dimengerti oleh khalayak ramai. Apabila kesengajaan seperti ini ada pada suatu tindak pidana, si pelaku pantas dikenakan hukuman pidana. Karena dengan adanya kesengajaan yang bersifat tujuan ini, berarti si pelaku benar-benar menghendaki mencapai suatu akibat yang menjadi pokok alasan diadakannya ancaman hukuman ini. 
2. Kesengajaan keinsyafan secara kepastian. Kesengajaan ini ada apabila si pelaku, dengan perbuatannya tidak bertujuan untuk mencapai akibat yang menjadi dasar dari delik, tetapi ia tahu benar bahwa akibat itu pasti akan mengikuti perbuatan itu.

3. Kesengajaan secara keinsyafan kemungkinan, (Pipin Saripin, 2000: 93).

Kesengajaan ini yang terang-terang tidak disertai bayangan suatu kepastian akan terjadi akibat yang bersangkutan, melainkan hanya dibayangkan suatu kemungkinan belaka akan akibat itu. Selanjutnya mengenai kealpaan karena merupakan bentuk dari kesalahan yang menghasilkan dapat dimintai pertanggung jawaban atas perbuatan seseorang yang dilakukannya, seperti yang tercantum dalam Pasal 359 KUHP "Barangsiapa karena kealpaannya menyebabkan matinya orang lain diancam dengan pidana penjara paling lama lima tahun atau kurangan paling lama satu tahun". Kealpaan mengandung dua syarat, yaitu:

a. Tidak mengadakan pendugaduga sebagaimana diharuskan hukum

b. Tidak mengadakan penghatihati sebagaimana diharuskan hukum Dari ketentuan di atas, dapat diikuti dua jalan, yaitu pertama memperhatikan syarat tidak mengadakan penduga-duga menurut semestinya. Yang kedua memperhatikan syarat tidak mengadakan penghati-hati guna menentukan adanya kealpaan. Siapa saja yang melakukan perbuatan tidak mengadakan penghati-hati yang semestinya, ia juga tidak mengadakan mendugaduga akan terjadi akibat dari kelakuannya. Selanjutnya ada kealpaan yang disadari dan kealpaan yang tidak disadari. Dengan demikian tidak mengadakan penduga-duga yang perlu menurut hukum terdiri atas dua kemungkinan yaitu:

a. Terdakwa tidak mempunyai pikiran bahwa akibat yang dilarang mungkin timbul karena perbuatannya.

b. Terdakwa berpikir bahwa akibat tidak akan terjadi ternyata tidak benar.

Kemudian syarat yang ketiga dari pertanggung jawaban pidana yaitu tidak ada alasan pembenar atau alasan yang menghapuskan pertanggung jawaban pidana bagi si pembuat. Dalam masalah dasar penghapusan pidana, ada pembagian antara "dasar pembenar" (permisibilry) dan "dasar pemaaf" (ilegal execuse). Dengan adanya salah satu dasar penghapusan pidana berupa dasar pembenar maka suatu perbuatan kehilangan sifat melawan hukumnya, sehingga menjadi legal/boleh, pembuatanya tidak dapat disebut sebagai pelaku tindak pidana. Namun jika yang ada adalah dasar penghapus berupa dasar pemaaf maka suatu tindakan tetap melawan hukum, namun si 
pembuat dimaafkan, jadi tidak dijatuhi pidana.

Dasar penghapus pidana atau juga bisa disebut alasanalasan menghilangkan sifat tindak pidana ini termuat di dalam Buku I KUHP, selain itu ada pula dasar penghapus diluar KUHP yaitu:

1. Hak mendidik orang tua wali terhadap anaknya/guru terhadap muridnya.

2. Hak jabatan atau pekerjaan. Yang termasuk dasar Pembenar pembelaan terpaksa Pasal 49 ayat (1) KUHP, keadaan darurat, pelaksanaan peraturan perundang-undangan Pasal 50, pemerintah jabatan-jabatan Pasal 51 ayat (1) terhadap dasar pemaaf atau fait d'excuse ini semua unsur tindak pidana, termasuk sifat melawan hukum dari suatu tindak pidana tetap ada, tetapi hal-hal khusus yang menjadikan si pelaku tidak dapat dipertanggung jawabkan, atau dengan kata lain menghapuskan kesalahannya. Yang termasuk dasar pemaaf adalah: kekurangan atau penyakit dalam daya berpikir, daya paksa (overmacht), pembelaan terpaksa, melampaui batas (noodweerexes), perintah jabatan yang tidak sah.

uraian mengan memperhatikan pertanggungjawaban pidana terhadap pelaku tindak pidana kehutanan dapat ditegakkan atas dasar:

1. Adanya perbuatan yang dilarang;

2. Dikerjakan dengan kemauan sendiri;
3. Pembuatnya mengetahui terhadap akibat perbuatan tersebut.

Dari tiga unsur tersebut, maka yang dapat dibebani pertanggung jawaban pidana adalah manusia yang berakal pikiran, dewasa dan berkemauan sendiri. Kalau tidak demikian maka tidak ada pertanggung jawaban pidana atasnya, karena orang yang tidak berakal pikiran bukanlah orang yang mengetahui dan bukan pula orang yang mempunyai pilihan. Oleh karena itu tidak ada pertanggungjawaban bagi anak kecil, orang gila, orang dungu orang hilang kemauannya, dan orang-orang yang dipaksa atau terpaksa.

E. Y. Kanter mengtakan bahwa, untuk menghubungkan pelaku dengan tindakannya dalam rangka pertanggungjawaban pidana pelaku atas tindakannya, agar dapat ditentukan pemidanaan kepada pelaku harus diteliti dan dibuktikan bahwa:

a. subjek harus sesuai dengan perumusan undang-undang;

b. terdapat kesalahan pada petindak;

c. tindakan itu bersifat melawan hukum;

d. tindakan itu dilarang dan diancam dengan pidana oleh undang-undang (dalam arti luas);

e. dan dilakukan tindakan itu sesuai dengan tempat, waktu dan keadaan-keadaan lainnya yang ditentukan dalam 
undang-undang, (E.Y. Kanter, 2002: 251).

Subjek hukum tindak pidana perusakan hutan dirumuskan dalam Pasal 1 angka 22, Pasal 12 dan Pasal 18 serta pasal-pasal Ketentuan Pidana Undang-Undang Nomor 18 Tahun 2013 Tentang Pencegahan dan Pemberantasan Perusakan Hutan bahwa "Setiap orang adalah orang perseorangan atau badan usaha, baik yang berbadan hukum maupun yang tidak berbadan hukum. Setiap orang adalah orang perseorangan. Korporasi adalah kumpulan orang dan/atau kekayaan yang teroganisasi, baik berupa badan hukum maupun bukan badan hukum.

Dengan demikian subjek hukum dalam tindak pidana perusakan hutan adalah manusia dan badan hukum. Subjek hukum yang dalam istilah Belanda meliputi "Persoon" dan "Rechtpersoon". "Persoon" adalah manusia atau orang yang

\section{Identitas Terdakwa}

a. Nama Lengkap

: SudirmanHutagaol anak dari M. Hutagaol;

b. Tempat lahir : Sigumpar (Prop. Sumatera Utara);

c. Umur/tgl lahir

d. Jenis Kelamin

e. Kebangsaan : 37 tahun/ 06 Februari 1977;

: Laki-laki; : Indonesia;

f. Tempat Tinggal : (1) Dusun Dam Siambang Desa Pemusiran Simpang T Kec. Mandiangin Kabupaten

Sarolangun Provinsi Jambi; (2) Rt. 11 Huta Baru Desa Batang Kumuh Kecamatan Tembusai Kab. Rokan Hulu Provinsi Riau.
g. A g a m a
: Kristen;
h. Pekerjaan

memiliki kewenangan untuk bertindak dalam lapangan hukum, khususnya hukum perdata. "Rechtpersoon" ialah badan hukum yang diberi kewenangan oleh undang-undang untuk dapat bertindak sebagaimana orang yang masuk dalam golongan "persoon".

Pasal 92 ayat (1) huruf a Undang-Undang Nomor 18 Tahun 2013, dirumuskan Orang perseorangan yang dengan sengaja melakukan kegiatan perkebunan tanpa izin Menteri di dalam kawasan hutan sebagaimana dimaksud dalam Pasal 17 ayat (2) huruf b.

Unsur objektif, yaitu unsur di luar diri si pelaku dan unsur subjektif yaitu unsur yang ada dalam diri si pelaku. Setiap unsur tersebut harus dibuktikan oleh Hakim. Untuk lebih jelasnya, berikut ini penulis paparkan Putusan Pengadilan Negeri Sarolangun Nomor 16/Pid. Sus/2015/PN.SRL. 
Terdakwa dalam perkara ini ditahan dengan perincian penahanan sebagai berikut; Penyidik sejak tanggal 2 Oktober 2014 sampai dengan tanggal 21 Oktober 2014; diperpanjang; Jaksa Penuntut sejak tanggal 21 Januari 2015 sampai dengan tanggal 3 Februari 205; Hakim Pengadilan Negeri dari tanggal 4 Februari sampai dengan tanggal 5 Maret 2015; Diperpanjang oleh ketua Pengadilan Negeri Sarolangun sampai dengan tanggal 4 Mei 2015.

Menimbang bahwa perbuatan terdakwa telah didakwa oleh Penuntut Umum dengan dakwaan alternatif, sehingga Majelis Hakim dengan memperhatikan faktafakta hukum tersebut di atas mempertimbangkan terlebih dahulu dakwaan ke satu sebagaimana diatur dalam Pasal 92 ayat (1) Huruf a jo pasal 17 ayat (2) huruf b Undang-Undang Nomor 18 Tahun $2013 \quad$ Tentang Pencegahan dan Pemberantasan Pengrusakan Hutan; yang unsur-unsurnya adalah sebagai berikut:

Menimbang, bahwa memperhatikan jenis Dakwaan Penuntut Umum yang disusun secara alternatif dimana memberikan opsi kepada Majelis Hakim untuk menentukan Dakwaan mana yang paling tepat terhadap perbuatan yang telah dilakukan oleh terdakwa; \begin{tabular}{lrr}
\multicolumn{2}{r}{ Menimbang, } & bahwa \\
setelah & Majelis & Hakim
\end{tabular} mencermati fakta hukum yang terungkap dipersidangan dan berdasarkan keterangan saksisaksi, keterangan terdakwa dan barang bukti yang diajukan dipersidangan, Majelis Hakim berpendapat bahwa dakwaan yang paling tepat terhadap terdakwa adalah Dakwaan PERTAMA sebagaimana diatur dan diancam pidana dalam Pasal 92 Ayat (1) huruf a Jo. Pasal 17 ayat (2) huruf b Undangundang RI Nomor 18 Tahun 2013 tentang pencegahan dan pemberantasan Pengerusakan Hutan, sebagaimana dibawah ini;

1. Orang Perorang;

2. Dengan Sengaja melakukan kegiatan Perkebunan Tanpa Izin Menteri di dalam Kawasan Hutan; Menimbang, bahwa Majelis Hakim akan mempertimbangkan satu persatu unsur-unsur pasal tersebut, apakah terbukti atau tidak perbuatn yang dilakukan Terdakwa dalam perkara ini, sebagaimana berikut dibawah ini:

Ad. 1. Orang Perorang:

Menimbang, bahwa yang dimaksud dengan kata Orang Perorang sama dengan kata setiap orang. Hal ini secara eksplisit ditegaskan dalam Pasal 1 ayat 21 UndangUndang RI Nomor 18 
Tahun 2013 Tentang

Pencegahan dan

Pemberantasan

Perusakan Hutan yang berbunyi sebagai

berikut; "Setiap orang adalah perseorangan dan/atau" korporasi yang melakukan perbuatan perusakan hutan;

Menimbang, bahwa menilik maksud dari rumusan pembuat Undang-undang terhadap sub unsur ini, secara interpretasi gramatikal maka dapat diformulasikan sebagai berikut;

1. Setiap orang adalah siapa saja orangnya yang dalam hal ini dia ditujukan kepada tiap subyek hukum dalam arti manusia, sebagai pendukung hak dan kewajiban yang dapat mempertanggungja wabkan perbuatannya sedangkan Perseorangan adalah yang berkaitan dengan orang secara pribadi;

2. Korporasi adalah kumpulan orang dan/atau kekayaan yang terorganisasi, baik berupa badan hukum maupun \begin{tabular}{crr}
\multicolumn{2}{c}{ bukan } & badan \\
hokum. & \\
Oleh & Karena & dalam \\
rumusan & Pasal & ini
\end{tabular} mengandung syarat alternatif dimana aturan hukum yang memberikan beberapa syarat (kondisi) yang jika salah satu syarat tersebut terpenuhi maka akibat hukum akan diterapkan. Karena syaratnya alternative maka cukup tepenuhi salah satu saja dari syarat tersebut dan akibat hukumnya sudah bisa diterapkan;

Menimbang, bahwa terdakwa dipersidangan pada pokoknya telah menerangkan bahwa, keseluruhan identitas yang tercantum dalam dakwaan Penuntut Umum adalah benar diri terdakwa sendiri, demikian pula keseluruhan saksi-saksi dipersidangan pada pokoknya telah menerangkan bahwa yang dimaksud dengan Sudirman Hutagaol Anak dari Manintang Hutagaol adalah diri terdakwa, yang saat ini dihadapkan dan diadili di persidangan Pengadilan Negeri Sarolangun; Menimbang, bahwa terdakwa dipersidangan juga telah ditanyakan oleh Majelis Hakim, apakah terdakwa ada hubungannya dengan badan usaha atau badan hukum, baik secara perkerjaan ataupun menerima upah dari pekerjaan tersebut, dan 
terdakwa mengatakan tidak ada;

Menimbang, bahwa oleh karenanya berdasarkan uraian di atas terebut maka jelas dan teranglah unsur setiap orang dapat dikenakan dalam sub unsur ini, karenanya unsur pertama pasal ini telah terpenuhi menurut hukum;

Ad.2. Dengan sengaja melakukan kegiatan Perkebunan Tanpa Izi Menteri

di dalam Kawasan Hutan; Menimbang, bahwa untuk membuktikan sub unsur ini Pengadilan akan mengemukakan pengertian dan fakta-fakta hukum sebagai berikut;

Menimbang, dalam unsur ini mengandung beberapa pengertian seperti terurai di bawah ini;

1. Dengan sengaja. Berbicara dengan sengaja atau kesengajaan, dalam hukum pidana kesengajaan dapat di bagi dalam beberapa macam yaitu sebagai berikut;

a. Sengaja atau opzet adalah "willen dan wetens artinya; "Pembuat harus menghendaki (willen) melakukan perbuatan tersebut: dan juga harus mengerti (wetens) akan akibat daripada perbuatan itu" sedangkan dilihat dari bentuknya dikenal tiga bentuk kesengajaan atau opzet yaitu:

1) Kesengajaan sebagai maksud yaitu "Si pembuat (dader)

mengehendaki akibat dari perbuatannya". Artinya pembuat sudah mengetahui

sebelumnya bahwa akibat dari perbuatannya tidak akan terjadi maka sudah barang tentu tidak akan melakukan perbuatan tersebut;

2) Kesengajaan sebagai kepastian atau keharusan. Dalam teori ini mengatakan bahwa: "Perbuatan yang dilakukan tidak bertujuan untuk mencapai akibat yang menjadi dasar dari delik, tetapi ia tahu benar bahwa akibat itu pasti akan mengikuti perbuatan itu";

3) Kesengajaan sebagai kesadaran akan kemungkinan pada dasarnya bentuk kesengajaan ini timbul: "Apabila seseorang melakukan sesuatu perbuatan dan menimbulkan sesuatu akibat tertentu";

Bahwa dengan kata lain adalah suatu kesengajaan tentunya berhubungan dengan sikap bathin seseorang yang didakwa melakukan tindak pidana, dan Majelis Hakim menyadari tidaklah mudah untuk 
menentukan sikap batin sesorang untuk menilai unsur diketahui atau patut diketahui itu, benar-benar ada pada diri si pelaku, lebihlebih bagaimanakah keadaan batinnya pada waktu orang tersebut melakukan

perbuatannya, oleh karena itulah sikap batinnya harus disimpulkan dari keadaan lahir yang tampak dari luar;

2. Melakukan kegiatan Perkebunan tanpa izin Menteri di dalam kawasan hutan. Bahwa terhadap pengertian sub unsur pasal ini pengadilan sependapat dengan Penuntut Umum;

Menimbang, bahwa berdasarkan fakta-fakta hukum dipersidangan maka diperoleh halhal sebagaimana yang terurai di bawah ini;

Menimbang, bahwa dengan demikian unsur pasal ini telah terpenuhi;

Menimbang, bahwa dari seluruh apa yang dipertimbangkan di atas, maka jelaslah bahwa perbuatan Terdakwa dalam perkara ini telah terpenuhi dan terbukti memenuhi unsur-unsur pasal yang didakwakan oleh Jaksa Penuntut Umum, yaitu telah melanggar Pasal 92 ayat (1) huruf a Jo. Pasal 17 ayat (2) huruf b Undang-Undang RI Nomor 18 Tahun 2013 Tentang Pencegahan dan Pemberantasan Pengrusakan Hutan dalam dakwaan Pertama: karenanya terdakwa harus dinyatakan terpenuhi dan terbukti melakukan tindak pidana "Dengan Sengaja Melakukan Kegiatan Perkebunan Tanpa Izin Menteri Di Dalam Kawasan Hutan"

Menimbang, bahwa selama pemeriksaan perkara berlangsung, Majelis Hakim tidak menemukan adanya alasan pembenar yang menghilangkan sifat melawan hukumnya perbuatan Terdakwa maupun alasan pemaaf yang dapat menghapuskan kesalahan Terdakwa, maka Terdakwa harus dijatuhi pidana yang setimpal dengan perbuatannya;

Menimbang, bahwa oleh karena terdakwa dinyatakan bersalah maka terdakwa juga dikenakan pidana denda yang akan ditentukan dalam amar keputusan di bawah ini dan apabila terdakwa tidak mampu membayar pidana denda tersebut, maka akan digantikan dengan penjara;

Menimbang, bahwa oleh karena selama pemeriksaan perkara Terdakwa berada dalam tahanan maka masa penahanan yang telah dijalani oleh terdakwa akan dikurangi sepenuhnya dari pidana yang dijatuhkan dan selain itu diperintahkan pula agar terdakwa tetap berada dalam tahanan;

Menimbang, bahwa mengenai barang bukti sebagaimana dibawah ini:

- 1 (satu) buah cangkul dengan gagang tersebut terbuat dari kayu; 
- 1 (satu) buah martil / palu dengan gagang tersebut terbuat dari kayu;

- 1 (satu) buah parang dengan gagang tersebut terbuat dari kayu;

- 1 (satu) buah mancis gas bewarna bening kombinasi ung

- 3 (tiga) batang kayu bekas bakar.

Berdasarkan

fakta

dipersidangan baik keterangan saksi-saksi dan terdakwa barang bukti ini merupakan dan berhubungan dengan terciptanya delik tersebut, karenanya akan dimusnahkan;

Menimbang, bahwa sebelum menentukan tinggi rendahnya pidana yang dijatuhkan terhadap diri Terdakwa perlu dipertimbangkan hal-hal yang memberatkan dan meringankan Terdakwa;

Hal-hal yang memberatkan:

- Perbuatan terdakwa mengakibatkan terjadinya kerusakan lingkungan dan ekosistem hutan;

Hal-hal yang meringankan:

- Terdakwa belum pernah dihukum;

- Terdakwa bersikap sopan dipersidangan;

- Terdakwa mengakui terus terang sehingga tidak mempersulit jalannya persidangan;

- Terdakwa menyesal dan berjanji tidak akan lagi mangulanginya;

Menimbang, bahwa

walaupun Terdakwa berdasarkan ketentuan dalam Pasal 92 ayat
(1) huruf a Jo. Pasal 17 ayat (2) huruf $b$ Undang-Undang RI Nomor 18 Tahun 2013 Tentang Pencegahan dan Pemberantasan Pengrusakan Hutan, dapat dijatuhi pidana penjara paling lama 10 (sepuluh) tahun dan denda paling banyak sebesar Rp. 5.000.000.000.00,- (lima milyar rupiah), atau menurut Tuntutan Pidana/Requisitoir Jaksa Penuntut Umum agar Terdakwa dijatuhi pidana penjara selama: 3 (Tiga) Tahun dan 3 (tiga) bulan serta menjatuhkan pidana denda sebesar Rp. 1.500.000.000.00,(satu milyar lima ratus juta rupiah), maka dengan memperhatikan hal-hal yang meringankan sebagaimana diuraikan di atas, dan dengan mengingat pula akan maksud dan tujuan pemidanaan di Negara kita yang nota bene berdasarkan PANCASILA dan UUD 1945, dimana pemidanaan tidak dimaksudkan sebagai tindakan balas dendam, melainkan sebagai upaya pendidikan/pengajaran kembali atau "pengayoman" kepada Terdakwa dan di lain pihak anggota masyarakat lainnya jangan sampai meniru atau mencontoh perbuatan yang sama (edukatif,korektif, dan preventif), maka cukuplah adil dan patut serta sesuai pula dengan rasa keadilan dalam masyarakat, jika Terdakwa dijatuhi pidana penjara dan denda yang lamanya dan besarnya seperti akan disebutkan selengkapnya dalam amar putusan ini; 
Mengingat Pasal 92 ayat (1) huruf a Jo. Pasal 17 ayat (2) huruf b Undang-undang RI Nomor 18 Tahun 2013 tentang Pencegahan dan Pemberantasan Pengrusakan Hutan, Undangundang No. 8 Tahun 1981 tentang Kitab Undang-undang Hukum Acara Pidana (KUHAP), Undang-Undang Nomor 48 Tahun 2009 Tentang Kekuasaan Kehakiman, Undang-Undang Nomor 49 Tahun 2009 Tentang Peradilan Umum dan peraturan lainnya yang berhubungan dengan perkara ini;

Mengadili:

1. Menyatakan Terdakwa Sudirman Hutagaol anak dari Manintang Hutagaol telah terbukti secara sah dan menyakinkan bersalah melakukan tindak pidana "dengan sengaja melakukan kegiatan perkebunan tanpa izin menteri di dalam kawasan hutan";

2. Menjatuhkan pidana terhadap Terdakwa tersebut dengan pidana penjara selama 3 (tiga) Tahun Penjara dan pidana denda sebesar RP. 1.500.000.000,- (satu milyar lima ratus juta rupiah), dengan ketentuan apabila denda tersebut tidak dibayar oleh Terdakwa maka akan diganti dengan pidana kurungan selam 1 (satu) bulan;

3. Menetapkan masa tahanan yang telah dijalani
Terdakwa dikurangkan seluruhnya dari pidana yang dijatuhkan;

4. Menetapkan Terdakwa tetap berada dalam tahanan;

5. Menetapkan barang bukti berupa:

1 (satu) buah cangkul dengan gagang tersebut terbuat dari kayu;

1 (satu) buah martil / palu dengan gagang tersebut terbuat dari kayu

1 (satu) buah parang dengan gagang tersebut terbuat dari kayu;

1 (satu) buah mancis gas bewarna bening kombinasi ung

3 (tiga) batang kayu bekas bakar.

Dimusnahkan;

6. Membebani Terdakwa membaya biaya perkara sebesar Rp. 5000,- (lima ribu rupiah);

Putusan hakim telah memuat dan menerapkan ketentuan hukum formal Undang-Undang Nomor 8 Tahun 1981 Tentang KUHAP Pasal 197 Ayat (1) huruf d, yaitu: pertimbangan yang disusun secara ringkas mengenai fakta dan keadaan beserta alat pembuktian yang diperoleh dari pemeriksaan di sidang yang menjadi dasar penentuan kesalahan terdakwa;

Menimbang, bahwa dari rangkaian keterangan saksisaksi dan dihubungkan dengan keterangan terdakwa ternyata 
dari substansinya terdapat ada persamaan dan persesuaian yang saling menguatkan. Atas dasar hal ini diperoleh faktafakta hukum.

Setelah Majelis Hakim mencermati fakta-fakta hukum yang terungkap dipersidangan dan berdasarkan keterangan saksi-saksi, keterangan terdakwa dan barang bukti yang diajukan ke persidangan. Majelis hakim berpendapat bahwa dakwaan yang paling tepat adalah dakwaan yang pertama sebagaimana diatur dan diancam pidana dalam Pasal 92 Ayat (1) huruf a Jo Pasal 17 ayat (2) huruf b Undang-Undang Nomor 18 Tahun $2013 \quad$ Tentang pencegahan Dan Pemberantasan pengrusakan Hutan.

Unsur Objektif yang berkaitan dengan unsur di luar diri si pelaku yang menyangkut perbuatan pidana atau perbuatan nyata dari pelaku dan unsur subjektif, yaitu unsur yang ada dalam diri pelaku, yaitu unsur sengaja. Untuk dapat dipertanggungjawabkan ke dua unsur, yaitu unsur objektif dan unsur subjektif harus dibuktikan.

Unsur objektif dan unsur subjektif diuraikan oleh Hakim secara detail dan atas pertimbangan tersebut Majelis Hakim yakin bahwa subyek hukum (terdakwa) bersalah, sehingga dijatuhkan pidana.

\section{Kesimpulan}

1. Hakim dalam menentukan unsurunsur Pasal 92 ayat (1) Huruf a Jo Pasal 17 ayat (2) huruf b UndangUndang Nomor 18 Tahun 2013 untuk dapat diterapkan kepada pelaku Pengrusakan Hutan (Analisis Putusan Pengadilan Negeri sarolangun Nomor: 16/PID.SUS/2015/PN.SRL., yaitu dengan membuktikan unsur objektif dan unsur subjektif dari Pasal 92 ayat (1) Huruf a Jo Pasal 17 ayat (2) huruf b UndangUndang Nomor 18 Tahun 2013 berdasarkan fakta di persidangan dan fakta yuridis serta hal-hal yang memberatkan dan meringankan secara sosiologis dari terdakwa. Unsur objektif dan unsur subjektif diuraikan oleh Hakim secara detail dan atas pertimbangan tersebut Majelis Hakim yakin bahwa subyek hukum (terdakwa) bersalah, sehingga dijatuhkan pidana.

2. Penentukan pertanggungjawaban pidana terhadap pelaku tindak pidana pengrusakan hutan sebagaimana diatur pada Pasal 92 ayat (1) Huruf a Jo Pasal 17 ayat (2) huruf b Undang-Undang Nomor 18 Tahun 2013 Tentang Tentang Pencegahan Dan Pengrusakan Hutan (Analisis Putusan Pengadilan Negeri sarolangun Nomor: 16/PID.SUS/2015/PN.SRL yaitu dengan memperhatikan Actus Reus dan guilty mind atau mens rea, yaitu adanya hubungan batin dengan perbuatan dan menurut ukuran yang biasa dipakai masyarakat sebagai ukuran untuk menetapkan ada 
tidaknya hubungan batin antara pelaku dengan perbuatan pidana Pasal 92 ayat (1) Huruf a Jo Pasal 17 ayat (2) huruf b UndangUndang Nomor 18 Tahun 2013). Pada pemeriksaan perkara berlangsung, Majelis Hakim tidak menemukan adanya alasan pembenar yang menghilangkan sifat melawan hukumnya perbuatan Terdakwa maupun alasan pemaaf yang dapat menghapuskan kesalahan Terdakwa, maka Terdakwa harus dijatuhi pidana yang setimpal dengan perbuatannya;

\section{S a r a n}

Dari kesimpulan yang telah diuraikan, berikut direkomendasikan hal-hal sebagai berikut:

1. Diharapkan kepada Majelis Hakim dalam menyusun putusan, secara teliti memperhatikan ketentuan hukum acara pidana khususnya unsur-unsur yang harus dipenuhi dalam Pasal 197 KUHAP.

2. Kepada Majelis hakim terus ditingkatkan dalam pengkajian aspek hukum materil berkaitan dengan konsep-konsep hukum yang harus dibuktikan dipersidangan.

\section{Daftar Pustaka}

Arif, Barda Nawawi, 2008. Bunga Rampai Kebijakan Hukum Pidana, Kencana, Jakarta.

Ali, Achmad, 1985. Menguak Tabir Hukum, Suatu Kajian Filosofis dan Sosiologis, Gunung Agung, Jakarta.
Dirdjosiworo, Soedjono, 1983.

Pengantar Ilmu Hukum. PT. RajaGrafindo Persada. Jakarta.

Koeswadji, Hermioen Hadiati, 1995. Perkembangan Macam-Macam Pidana Dalam Rangka pembangunan Hukum Pidana, Citra Aditya Bhakti, Bandung.

Kusumaatmadja, Mochtar, 1977. Hukum, Masyarakat dan Pembinaan Hukum Nasional, Binacipta, Bandung.

Kanter, E.Y, 2002. Asas-Asas Hukum Pidana di Indonesia, Sinar Grafika, Jakarta.

Loqman, Loeby, 2001. Pidana dan Pemidanaan. Datacom. Jakarta.

P.A.F. Lamintang, P.A.F, 1992. DasarDasar Hukum Pidana Indonesia, Sinar Baru, Bandung.

Narzuki, Peter Mahmud, 2014. Penelitian Hukum, Prenadamedia, Jakarta.

Mertokusumo, Sudikno, 1993. Bab-Bab Tentang Penemuan Hukum. Citra Aditya Bakti. Yogyakarta.

Muladi dan Barda NA, 1992. Teori-Teori dan Kebijakan Pidana, Alumni, Bandung.

Rahardjo, Satjipto, 1980. Hukum dan Masyarakat, Angkasa, Bandung.

Sunarso, Siswanto, 2005. Hukum Pidana Lingkungan Hidup dan Strategi Penyelesaian Sengketa. Rineka Cipta. Jakarta.

Syarifin, Pipin, 2000. Hukum Pidana di Indonesia. Pustaka Setia, Bandung.

Soedarto, 1990. Hukum Pidana I. Cetakan ke II, Yayasan Sudarto, Semarang.

Republik Indonesia, Undang-Undang Nomor 18 Tahun 2013 Tentang Pencegahan dan 
Perusakan Hutan. LNRI

Tahun 2013 Nomor 130.

JURUSAN ILMU HUKUM, UNDIKSHA

ISSN : 2407-4276 (ONLINE); ISSN : 2356-4164 (PRINT) 